\title{
The Influence Factors Decomposition of Grain Output Increase in China: 2003-2014
}

\author{
Xiaoquan Hua ${ }^{1}$ \\ ${ }^{1}$ School of Economics and Management, Huainan Normal University, Huainan, Anhui, China \\ Correspondence: Xiaoquan Hua, School of Economics and Management, Huainan Normal University, Quanshan \\ Road, Huainan, Anhui 232038, China. Tel: 86-0554-686-3905. E-mail: huaxq2007@126.com
}

Received: August 2, 2016

Accepted: September 7, $2016 \quad$ Online Published: October 15, 2016

doi:10.5539/jas.v8n11p59

URL: http://dx.doi.org/10.5539/jas.v8n11p59

The research is financed by "The Humanities and Social Science Foundation of Anhui Educational Department" (SK2016A0846).

\begin{abstract}
As the world's most populous country taking up $18.84 \%$ of the world's total population, China's grain supply has attracted high concerns in the world. This article takes the grain output increase in China from 2003 to 2014 as the research object, and wants to explore the influence factors of China's grain growth and spatial effect analysis. It employs LMDI method to decompose China's total grain output increase during 2003-2014. The increase of OFPPU paid maximum contribution to China's total grain output increase among ACL, MCI and GPP. The conclusion of China's grain output provincial spatial analysis is that the six provinces including Heilongjiang, Henan, Inner Mongolia, Jilin, Anhui and Shandong, contributed 62.2\% share to China's increase. The results of predicted OFPPU by Exponential Smoothing Method of Hoter-Winter No-Seasonal are that grain growth in China can meet requirements of grain security for China's population growth and living improvement. The author wishes China can increase investment on land consolidation and renovate facilities for farmland and water conservancy projects.
\end{abstract}

Keywords: index decomposition, grain output increase, spatial analysis

\section{Introduction}

As the world's most populous country of $18.84 \%$ world's total population, China's grain supply has attracted global attentions of the world in 1990s after a article titled 'who will feed China?' published by Lester Brown, director of the World Watch Institute in the United States in 1994. In the article, he claimed that China's population would reach 1.6 billion in early twenty-first Century, and food supply would fall behind its demand. The food price would rise if China imports food from the world market, which would cause the world's food crisis. Over the past 20 years, China's population had reached 1.375 billion by the end of 2015, China's grain output reached 621.44 million tons, $445.5 \mathrm{~kg}$ per capita, and this year witnessed grain output growth in 12 consecutive years.

Scholars have maintained high enthusiasm for the topic of food supply and demand in China despite China's grains production improved rapidly since 1980s because of the household-contract-responsibility-system extension in rural. Hong and Xiubin (2000) studied connection between cultivated land and food supply in China; Peter et al. (2000) analyzed the spatial exploration characteristics of land use change and grain production in China; Jie (2006) focused on the challenge of soil protection and food security along with rapid urbanization in China; Conflict between food security and conservation has never ceased in recent years in China (Zhigang et al., 2005); environmental change and resilience to drought of three major food crops in China became more and more outstanding in recently decades (Elisabeth et al., 2005); Hong et al. (2009) worried about negative effect of biofuel large-scale implications for food supply. The existing quantitative analysis of China's grain production was lack, and researcher paied little attention to the space unbalanced between supply and demand of broad land China.

The single-child policy (Note 1), which has been implemented since 1980, was ended in China in 2016. Now a couple is allowed to have two children, while a couple is even allowed to have three children in remote areas 
such as some districts in Heilongjiang Province. Will this policy set off an explosion of China's population? Can limited food production in China meet a rising demand of China's growing population and increasing demand from poor people after shaking off poverty? This paper will analyze the influence factors of China's grain output in the past, and predict the imbalance between grain supply and demand in the future in China.

This article is organized as follows: the first part is the introduction, explaining why China's grain growth is chosen as the research topic; the second part describes the characteristics of food production and consumption in China in nearly 30 years; the third part introduces the research methods on China's grain growth, and analyzes different contribution factors to China's grain growth; the fourth part studies the spatial distribution to China's grain growth and describes the spatial characteristics of grain supply and demand gap with province as a unit; the fifth part predicts grain gap between supply and demand in China in next 15 years by using Hoter-Winter No-Seasonal method; the last part is the conclusions and suggestions of this article.

\section{Descriptions of Grain Output in China}

In the future the challenge of China's grain supply comes from three aspects: one is the China's accelerated industrialization and urbanization. In this stage, a large population transfer from rural areas to urban areas, from agriculture to industry and service. In China as a large number of rural young labors transfer from agriculture to industry; the elders, women, and children are engaged in agricultural production to supply grain crops for 1.375 billion Chinese with random planting, which pays attention to grain quantity instead of quality and safety.

The second factor is that farmland area decreased rapidly with city expansion in China. It is estimated that about 500 thousand acres (34 thousand hectares) farmland disappeared annually. China's Ministry of Land and Resources demanded that the total cultivated land should keep balance through cultivating new land to make up the loss. In fact, the new land is not ready for agriculture production, which is only a response to inspection of the Ministry of Land and Resources.

The third factor is low profit of China's agriculture. The China's government promoted agricultural modernization through developing large-scale farmlands, in order to solve the problem of low-efficient land use caused by land fragmentation. In the early 1980 's, the transition of agricultural production form from collective organization to family tenant management system promoted grain production rapidly in China, while rural land was divided into small pieces to ensure fair distribution of better farmlands. The lack of agricultural inputs by government have cause economic loss of small farming. A large number of small-scale falmlands were no longer under cultivation in China's rural area. In 2016, grain price fell while the average commodity price has beening rising. So, few capitalists are engaged in agricultural production in China.

Figure 1 shows the line diagram of grain total output and net import volume (import-export) after 1978 in China. According to Figure 1, the period of China's grain production from 1978 to now can be divided into four stages: the first stage is from 1978 to 1990. In this stage, grain output has maintained a faster growth because of institutional bonus from extension of family tenant management system in China; The second stage is from 1991 to 1998. In this stage, grain production kept growing slowly with fluctuations. The rural factories boomed and peasants entered into factory from fields because of high income. Prior to this, city factories only accept urban labors and refuse rural labors in China; The third stage is from 1999 to 2003. In this stage, grain output declined steadily. From the late 1990s, the tax burden of China's rural areas increased rapidly. So a large number of peasants were forced to go out for living with farmland abandoned. Two books described the current situation in Chinese rural. One is 'I Tell Prime Minister Truth' writen by Changping Li, a town's mayor of Hubei province. Another is 'The Survey of China's Peasants' writen by Guidi Chen and Chuntao, a couple scholars in Hefei city, Anhui province; The fourth stage is from 2004 to now. In this stage, grain output has maintained steady growth. In 2006, government abolished agricultural tax nationwide which had been implemented for 2600 years in China Refering to the provisions of WTO, the central government would offer agricultural subsidies to peasants. In 2015, peasants were subsidized by 250 yuan RMB (about \$40) per mu (666.7 square meters) from government. The policy of agricultural subsidy increases the enthusiasm of peasants, and farm production became profitable.

But some Chinese citizens especially rich people don't trust Chinese grain products. They think that the taste of China's grain grain is not good, and worry about grain food safety because of excessive use of chemical fertilizers and pesticides in the process of grain production. So they choose imported grain products. Shown by Figure 1, China's grain net import total has increased significantly since 2003, and reached 1.03 hundred million tons in 2014, accounting for about $1 / 6$ of China's total grain output in this year. 


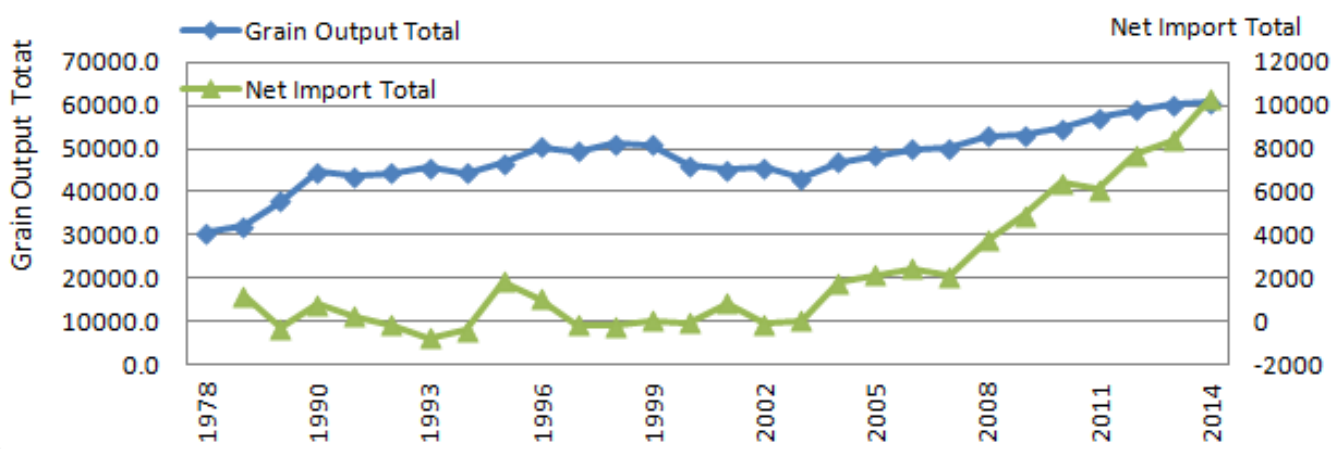

Figure 1. The grain output total and net import total in China: 1978-2014

Note. Unit: million tons.

Source: China Statistical Yearbook (2015). Beijing: China Statistical Press.

Comparing grain supply in several countries in East Asia from Figure 2, we found that the situation of East Asia's grain supply is similar to China's, and China's grain supply almost determines the trend of East Asian's. The capacity of China's grain supply is better than that of India and Japan, but worse than that of South Korea, while these countries have similar food structure with grain consumption as mainly.

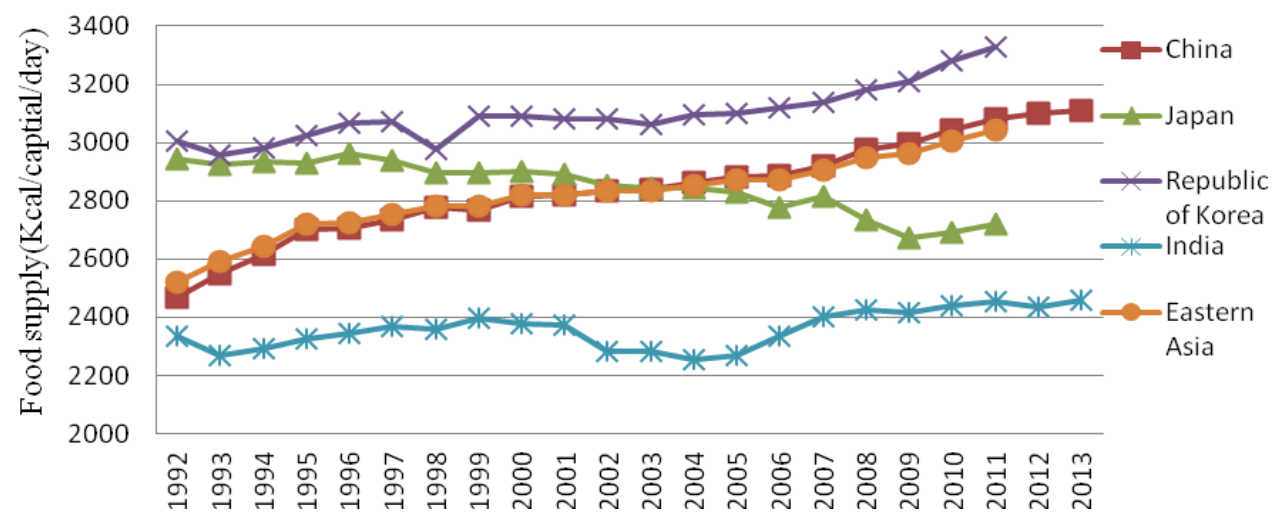

Figure 2. Food supply in selected country (Kcal/captial/day): 1992-2013

Source: FAOSTAT. Retrieved from http://faostat3.fao.org/browse/FB/*/E

\section{LMDI Decomposition Method and Application to Grain Output Increase in China}

\subsection{Method of Grain Output LMDI Decomposition}

Quantitative analysis of influence factors of grain output in China is usually used by two methods. The first method is production function. By establishing input-output function of grain production, we get the contribution of input-factors change to grain output. In China, Cobb-Douglass production function and transcendental logarithmic production function model is used frequently. But the input factors of production function and the selection method of production function is doubted, so the reliability of the conclusion obtained from production function method is regard as poor. The second method is the factor decomposition method of Logarithmic Mean Divisia Index-LMDI, which was first used by Ang B. W. in 1998. Benefiting from residual error limination of the traditional regression equation, LMDI method was often used in decomposition of carbon emissions growth for achieving complete decomposition of influence factors (Zhang et al., 2001; Ang, 2005). This approach is rather effective in solving a number of variable contributions to the growth total in a country.

In this paper, the LMDI method applied to China's grain output growth is as follows: 


$$
\begin{aligned}
& \text { Total quantity of grain production }=\text { Area of cltivated land } \times \frac{\text { Total sown area }}{\text { Area of cultivated land }} \\
& \qquad \times \frac{\text { Sown area of grain crops }}{\text { Total sown area }} \times \frac{\text { Total quantity of grain production }}{\text { Sown area of grain crops }} \\
& \frac{\text { Total sown area }}{\text { Area of cultivated land }}=\text { Multiplecropindex } \\
& \frac{\text { Sown area of graincrops }}{\text { Total sown area }}=\text { Grain planting proportion } \\
& \frac{\text { Total quantityof grain production }}{\text { Sown area of graincrops }}=\text { Output of farm product per unit }
\end{aligned}
$$

Therefore, in one year total quantity of grain production-TQGN is equal to multiply continuously of four factors: area of cultivated land-ACL, multiple crop index-MCI, grain planting proportion-GPP and output of farm product per unit-OFPPU. The identity in Equation (1) may be writen as:

$$
T Q G N=\sum T Q G N_{i}=\sum A C L_{i} \times M C I_{i} \times G P P_{i} \times O F P P U_{i}
$$

In Equation (5), the total quantity of grain production is divided into TQGN sum of $i$ district. $D T Q G N$ or $\triangle T Q G N$ represent the aggregate change from $T Q G N_{0}$ in time 0 to $T Q G N_{t}$ in time $t$. In multiplicative decomposition, the ratio is decomposed as follows:

$$
D_{T Q G N}=T Q G N^{t} / T Q G N^{0}=D_{A C L} \times D_{M C I} \times D_{G P P} \times D_{O F P P U}
$$

\begin{tabular}{|c|c|c|}
\hline Identity & $T Q G N=\sum T Q G N_{i}=\sum A C L_{i} \times M C I_{i} \times G P P_{i} \times O F P P U_{i}$ & \\
\hline \multirow[t]{2}{*}{ Change scheme } & Multiplicative Decomposition & Additive Decomposition \\
\hline & $D T Q G N=T Q G N_{t} / T Q G N_{0}=D A C \times D M C I \times D G P P \times D O F P P U$ & $\triangle T Q G N=T Q G N_{t}-T Q G N_{0}=\triangle A C L+\triangle M C I+\triangle G P P+\triangle O F P P U$ \\
\hline \multirow[t]{4}{*}{ LMDI fomulae } & $D_{A C L}=\operatorname{Exp}\left(\sum_{i} \frac{\left(T Q G N_{i}^{t}-T Q G N_{i}^{0}\right) /\left(\ln T Q G N_{i}^{t}-\ln T Q G N_{i}^{0}\right)}{\left(T Q G N^{t}-T Q G N^{0}\right) /\left(\ln T Q G N^{t}-\ln T Q G N^{0}\right)} \times \ln \left(\frac{A C L_{i}^{t}}{A C L_{i}^{0}}\right)\right)$ & $\triangle A C L=\sum_{i} \frac{T Q G N_{i}^{t}-T Q G N_{i}^{0}}{\ln T Q G N_{i}^{t}-\ln T Q G N_{i}^{0}} \times \ln \left(\frac{A C L_{i}^{t}}{A C L_{i}^{0}}\right)$ \\
\hline & $D_{M C I}=\operatorname{Exp}\left(\sum_{i} \frac{\left(T Q G N_{i}^{t}-T Q G N_{i}^{0}\right) /\left(\ln T Q G N_{i}^{t}-\ln T Q G N_{i}^{0}\right)}{\left(T Q G N^{t}-T Q G N^{0}\right) /\left(\ln T Q G N^{t}-\ln T Q G N^{0}\right)} \times \ln \left(\frac{M C I_{i}^{t}}{M C I_{i}^{0}}\right)\right)$ & $\Delta M C I=\sum_{i} \frac{T Q G N_{i}^{t}-T Q G N_{i}^{0}}{\ln T Q G N_{i}^{t}-\ln T Q G N_{i}^{0}} \times \ln \left(\frac{M C I_{i}^{t}}{M C I_{i}^{0}}\right)$ \\
\hline & $D_{G P P}=\operatorname{Exp}\left(\sum_{i} \frac{\left(T Q G N_{i}^{t}-T Q G N_{i}^{0}\right) /\left(\ln T Q G N_{i}^{t}-\ln T Q G N_{i}^{0}\right)}{\left(T Q G N^{t}-T Q G N^{0}\right) /\left(\ln T Q G N^{t}-\ln T Q G N^{0}\right)} \times \ln \left(\frac{G P P_{i}^{t}}{G P P_{i}^{0}}\right)\right)$ & $\Delta G P P=\sum_{i} \frac{T Q G N_{i}^{t}-T Q G N_{i}^{0}}{\ln T Q G N_{i}^{t}-\ln T Q G N_{i}^{0}} \times \ln \left(\frac{G P P_{i}^{t}}{G P P_{i}^{0}}\right)$ \\
\hline & $D_{\text {OFPPU }}=\operatorname{Exp}\left(\sum_{i} \frac{\left(T Q G N_{i}^{t}-T Q G N_{i}^{0}\right) /\left(\ln T Q G N_{i}^{t}-\ln T Q G N_{i}^{0}\right)}{\left(T Q G N^{t}-T Q G N^{0}\right) /\left(\ln T Q G N^{t}-\ln T Q G N^{0}\right)} \times \ln \left(\frac{O F P P U_{i}^{t}}{O F P P U_{i}^{0}}\right)\right)$ & $\triangle O F P P U=\sum_{i} \frac{T Q G N_{i}^{t}-T Q G N_{i}^{0}}{\ln T Q G N_{i}^{t}-\ln T Q G N_{i}^{0}} \times \ln \left(\frac{O F P P U_{i}^{t}}{O F P P U_{i}^{0}}\right)$ \\
\hline
\end{tabular}

In additive decomposition, the difference is decomposed as follows:

$$
\triangle T Q G N=T Q G N^{t}-T Q G N^{0}=\triangle A C L+\triangle M C I+\triangle G P P+\triangle O F P P U
$$

The formulation process of Equations (6) and (7) are summarized in Table 1.

Table 1. LMDI formulae for decomposing in TQGN

\subsection{Results of LMDI Decomposition}

Through 12-year consecutive growth, the total grain output rose from 430.695 million tons, or $333.3 \mathrm{~kg}$ per capita in 2003 to 621.44 million tons, or $445.5 \mathrm{~kg}$ per capita in 2015 in China. The growth rate of China's grain output per capita has averaged $2.90 \%$ annually, which is rare in the grain crops production history in the World. China's grain production capacity shows that China is capable of feeding 1.6 billion people in the future, which has taken up for nearly $22 \%$ of world's total population.

Next, we will use the LMDI method to decompose China's total grain output increase from 2003 to 2014 (the detail data of 2015 in China hasn't published openly up to now). The results are shown in Tables 2 and 3. 
Table 2. Results of total grain output decomposition for China, 2003-2014: multiplicative decomposition

\begin{tabular}{lllll}
\hline DTQGN & DACL & DMCI & DGPP & DOFPPU \\
\hline 1.4094 & 1.0311 & 1.0522 & 1.0457 & 1.2424 \\
\hline
\end{tabular}

Table 3. Results of total grain output decomposition for China, 2003-2014: additive decomposition (million tons)

\begin{tabular}{lllll}
\hline$\Delta$ TQGN & $\Delta$ ACL & $\Delta$ MCI & $\Delta$ GPP & $\Delta$ OFPPU \\
\hline 1763.3 & 157.35 & 261.38 & 229.38 & 1115.21 \\
\hline
\end{tabular}

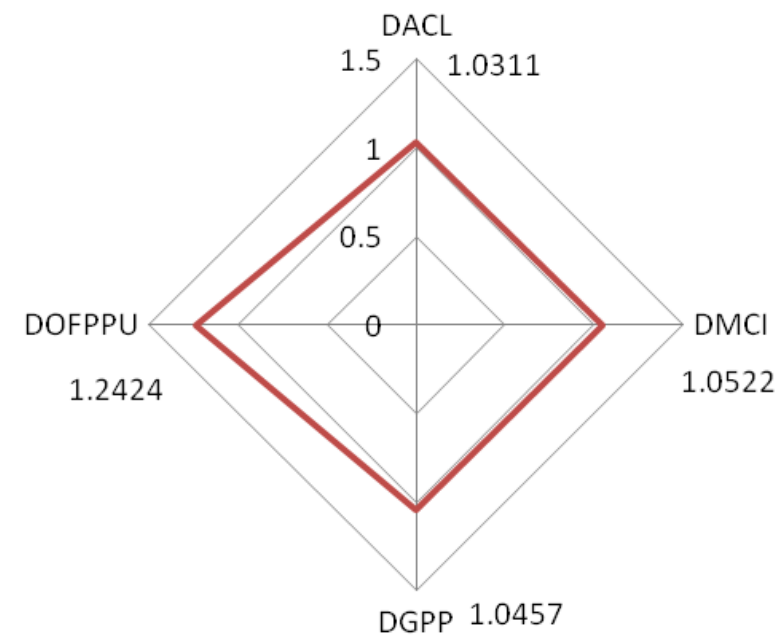

Figure 3. Presentation of multiplication decomsition results in Table 2

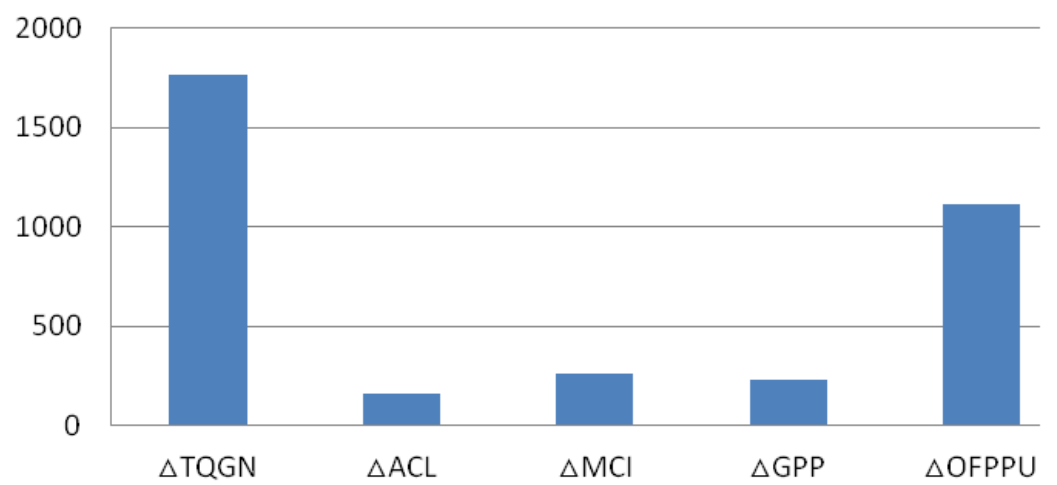

Figure 4. Presentation of additive decomsition results in Table 3 (million tons)

Figures 3 and 4 drawn according to Tables 2 and 3 more clearly show the comparable decomposition results of various factors. The increase of OFPPU made maximum contribution to China's total grain output increase during 2003-2014. From 2003 to 2014, China's total grain output has increased by 1763.3 million tons or $40.94 \%$. The LMDI decomposition results showed that the increase of OFPPU led to total grain output increase of 1115.21 million tons or $24.24 \%$. The increase of DMI led to total grain output increase of 261.38 million tons or $5.22 \%$, and the increase of GPP led to an increase of 229.38 million tons or $4.57 \%$. The increase of ACL made minimum contribution to China's total grain output increase, only leading to an increase of 157.35 million tons or $3.11 \%$. 


\section{The Spatial Analysis of Grain Output in China}

China's total population has reached 1.374 billion at the end of 2015, the largest in the world, distributed in a wide area of 31 provinces with Hongkong, Macao Special Administrative Region and Taiwan Province excluded. Especially since the 1990s, a large amount of rural population coming from middle and west provinces flows to southeastern regions of China to find jobs to earn money, attracted by strong economy growth in this districts such as Guangdong, Zhejiang, Jiangsu and Fujian Provinces. According to statistics published by China's National Bureau, the migrating population in 2014 reached 252 million in China. However, the affluent provinces of land area per capita, including Heilongjiang, Inner Mongolia, Jilin and Xinjiang, has relatively fewer population. Thus, the space distribution between grain output and demand in China remains imbalance.

In ancient China, the approach for space coordination between grain output and demand is river transportation. The Grand Canal, which was built in the Sui dynasty, has served as the channel of grain crops transportation in ancient China until railway became popular.

In China, due to poor profit of grain production, few provinces are willing to engage in it. Regional leaders are willing to develop industries for more fiscal revenue. So over a long time after the foundation of P.R.C. independence, grain crops was always in short supply. The implementation policy of the central government is "the governor of province should be responsible for grain output and supply of their provincal residents".

In order to investigate the spatial characteristics for China's grain output increase during 2003-2014, we build a matrix of grain production and growth in China. Table 4 shows that there are 14 provinces belong to Dog style with both low base of grain output and low growth rate in China from 2003 to 2014 . There are only 6 provinces matching Star style with both high base of grain output and high growth rate, whose four are located in the northeast China and the remaining two are in the middle. So now the traditional grain transportation from south to north has changed into the one from north to south in China.

Table 4. The spatial matrix of grain output increase in china, 2003-2014

\begin{tabular}{lll}
\hline & Low base of grain output per capita & High base of grain output per capita \\
\hline Low increase rate & Dog style: & Taurus style: \\
& $\begin{array}{l}\text { Beijing, Hebei, Shanxi, Shanghai, Zhejiang, Fujian, } \\
\text { Guangdong, Guangxi, Hainan, Guizhou, Yunnan, }\end{array}$ & $\begin{array}{l}\text { Liaoning, Shandong, Hubei, Hunan, } \\
\text { Thongqing, Sichuan, Ningxia }\end{array}$ \\
& Tibet, Shaanxi, Qinghai & \\
\hline High increase rate & Infant style: & Star style: \\
& Tianjin, Jiangsu, Gansu, Jiangxi & Inner Mongolia, Jilin, Xinjiang, \\
& & Heilongjiang, Henan, Anhui \\
\hline
\end{tabular}

Using the LMDI method to decompose China's province total grain output increase from 2003 to 2014, we obtained the contribution of provincal influence factors to total grain output increase in China. The results are shown in Table 5. 
Table 5. Results of total grain output LDMI decomposition for China province, 2003-2014

\begin{tabular}{|c|c|c|c|c|c|c|c|c|c|c|}
\hline \multirow[t]{2}{*}{ District } & \multicolumn{2}{|c|}{ Total contribution } & \multicolumn{2}{|c|}{$\begin{array}{c}\text { Contribution of } \\
\text { aclchange }\end{array}$} & \multicolumn{2}{|c|}{$\begin{array}{c}\text { Contribution of } \\
\text { MIC change }\end{array}$} & \multicolumn{2}{|c|}{$\begin{array}{l}\text { Contribution of } \\
\text { GPP change }\end{array}$} & \multicolumn{2}{|c|}{$\begin{array}{l}\text { Contribution of } \\
\text { OFPPU change }\end{array}$} \\
\hline & Output & Percentage & Output & Percentage & Output & Percentage & Output & Percentage & Output & Percentage \\
\hline Beijing & 0.59 & 0.03 & -2.69 & -1.71 & -0.08 & -0.03 & 1.78 & 0.78 & 1.58 & 0.14 \\
\hline Tianjin & 5.67 & 0.32 & -1.49 & -0.95 & 0.83 & 0.32 & 4.93 & 2.15 & 1.40 & 0.13 \\
\hline Hebei & 97.24 & 5.51 & -14.08 & -8.95 & 16.52 & 6.32 & 15.55 & 6.78 & 79.24 & 7.11 \\
\hline Shanxi & 37.19 & 2.11 & -13.83 & -8.79 & 16.12 & 6.17 & 14.53 & 6.34 & 20.37 & 1.83 \\
\hline Inner Mongolia & 139.23 & 7.90 & 22.69 & 14.42 & 25.88 & 9.90 & 17.17 & 7.49 & 73.48 & 6.59 \\
\hline Liaoning & 25.56 & 1.45 & 28.93 & 18.39 & -10.60 & -4.05 & 8.42 & 3.67 & -1.20 & -0.11 \\
\hline Jilin & 127.32 & 7.22 & 64.94 & 41.27 & -15.26 & -5.84 & 12.96 & 5.65 & 64.69 & 5.80 \\
\hline Heilongjiang & 372.99 & 21.15 & 122.23 & 77.68 & -31.70 & -12.13 & 59.30 & 25.85 & 223.16 & 20.01 \\
\hline Shanghai & 1.38 & 0.08 & -5.45 & -3.46 & 3.75 & 1.44 & 2.81 & 1.22 & 0.26 & 0.02 \\
\hline Jiangsu & 101.88 & 5.78 & -29.42 & -18.70 & 29.31 & 11.21 & 42.34 & 18.46 & 59.65 & 5.35 \\
\hline Zhejiang & -3.60 & -0.20 & -5.55 & -3.53 & -11.53 & -4.41 & 7.80 & 3.40 & 5.68 & 0.51 \\
\hline Anhui & 120.10 & 6.81 & -4.14 & -2.63 & -1.35 & -0.52 & 25.96 & 11.32 & 99.64 & 8.93 \\
\hline Fujian & -4.61 & -0.26 & -4.78 & -3.03 & -1.34 & -0.51 & -8.06 & -3.52 & 9.57 & 0.86 \\
\hline Jiangxi & 69.32 & 3.93 & 5.48 & 3.48 & 13.79 & 5.27 & 14.82 & 6.46 & 35.23 & 3.16 \\
\hline Shandong & 116.11 & 6.58 & -2.90 & -1.84 & 8.46 & 3.24 & 53.54 & 23.34 & 57.02 & 5.11 \\
\hline Henan & 220.28 & 12.49 & 1.71 & 1.09 & 20.96 & 8.02 & 39.05 & 17.03 & 158.56 & 14.22 \\
\hline Hubei & 66.32 & 3.76 & 14.53 & 9.24 & 14.07 & 5.38 & 17.40 & 7.59 & 20.31 & 1.82 \\
\hline Hunan & 55.85 & 3.17 & 13.16 & 8.36 & 20.86 & 7.98 & -8.59 & -3.74 & 30.42 & 2.73 \\
\hline Guangdong & -7.31 & -0.41 & -30.88 & -19.62 & 26.87 & 10.28 & -9.99 & -4.35 & 6.69 & 0.60 \\
\hline Guangxi & 6.93 & 0.39 & 0.39 & 0.25 & -8.97 & -3.43 & -9.90 & -4.32 & 25.41 & 2.28 \\
\hline Hainan & -1.80 & -0.10 & -0.93 & -0.59 & -0.11 & -0.04 & -5.18 & -2.26 & 4.42 & 0.40 \\
\hline Chongqing & 5.74 & 0.33 & -21.92 & -13.93 & 27.56 & 10.54 & -16.37 & -7.14 & 16.48 & 1.48 \\
\hline Sichuan & 32.08 & 1.82 & 27.61 & 17.55 & -18.03 & -6.90 & -5.58 & -2.43 & 28.08 & 2.52 \\
\hline Guizhou & 3.42 & 0.19 & -8.44 & -5.36 & 27.98 & 10.70 & -15.28 & -6.66 & -0.84 & -0.08 \\
\hline Yunnan & 38.97 & 2.21 & -5.29 & -3.36 & 42.28 & 16.18 & -19.97 & -8.71 & 21.95 & 1.97 \\
\hline Tibet & 0.14 & 0.01 & 1.92 & 1.22 & -1.23 & -0.47 & -1.21 & -0.53 & 0.65 & 0.06 \\
\hline Shaanxi & 22.94 & 1.30 & -27.28 & -17.34 & 32.64 & 12.49 & -6.97 & -3.04 & 24.55 & 2.20 \\
\hline Gansu & 36.93 & 2.09 & 6.55 & 4.16 & 7.66 & 2.93 & -1.84 & -0.80 & 24.56 & 2.20 \\
\hline Qinghai & 1.80 & 0.10 & -1.50 & -0.95 & 3.13 & 1.20 & -0.47 & -0.20 & 0.64 & 0.06 \\
\hline Ningxia & 10.77 & 0.61 & 0.31 & 0.20 & 3.03 & 1.16 & -4.72 & -2.06 & 12.16 & 1.09 \\
\hline Xinjiang & 63.90 & 3.62 & 27.46 & 17.45 & 19.88 & 7.60 & 5.13 & 2.24 & 11.43 & 1.03 \\
\hline
\end{tabular}

Note. The unit of output is million tons.

From Table 5 we found that the six provinces including Heilongjiang, Henan, Inner Mongolia, Jilin, Anhui and Shandong, contributed $62.2 \%$ share to China's total grain output increase from 2003 to 2014. As China's major grain producing provinces, the increase of OFPPU in these six provinces contributed $38.4 \%$ share to China's total grain output increase from 2003 to 2014. In these six main grain production provinces, only Shandong province is the relatively developed region while the other five provinces are less developed regions in China. This brings challenge to China's more and more big regional gap, because developed region believe they can solve the problem of food supply through increasing income while the less developed region get confined because of low-profit of grain production and slim possibilities of rapid industrial development. As a result, only central government pay enough attention to grain production in China.

The gap of per capita grain reflects the gap between grain output and demand. Figure 5 is four sub bitmap of provincial grain gap per capita in China in 2003 and 2014. Comparing four sub bitmap of provincial grain gap per capita in 2003 with that in 2014, Figure 5 shows that the gap between grain supply and demand in China has little provincial space change. The 8 provinces of maximum grain gap per capita in 2014 have remained the same compared with that in 2003. But 8 provinces of the minimum grain gap per capita (i.e. maximum grain surplus 
per capita) in 2014 have changed. Henan, Anhui and Jiangxi provinces have maximum grain surplus per capita replacing Chongqing, Sichuan and Shandong province. As for the degree of maximum grain gap per capita include Beijing, Tianjin, Shanghai, Zhejiang, Fujian, Guangdong and Qinghai provinces have not changed from 2003 to 2014.

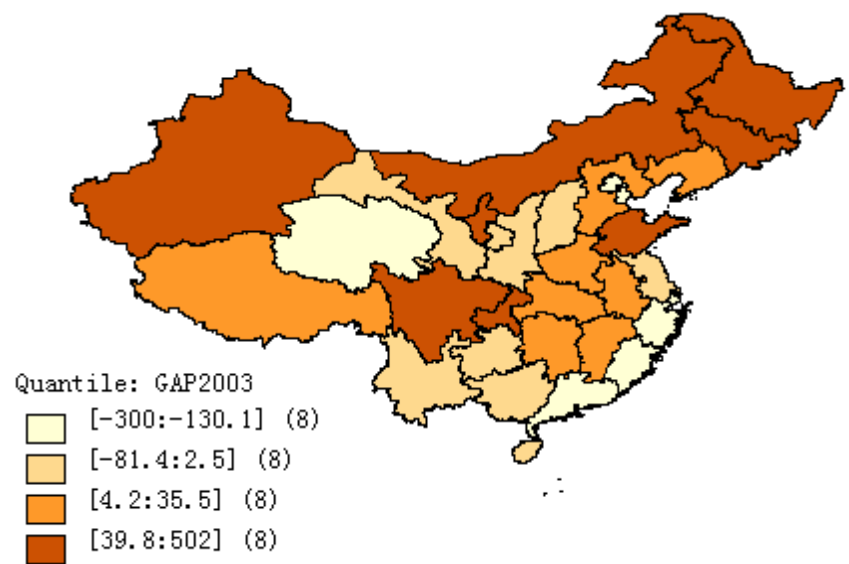

Figure 5(a). Four sub bitmap of provincial grain gap per capita in 2003

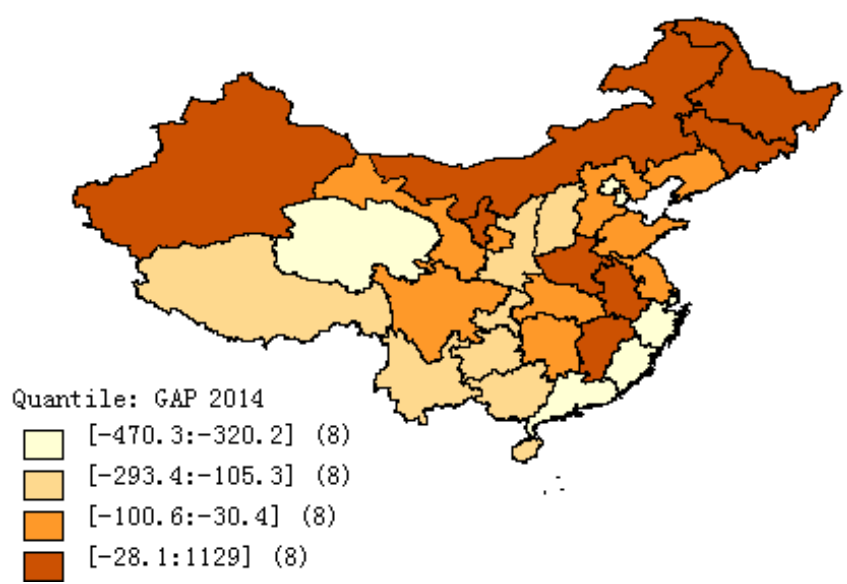

Figure 5(b). Four sub bitmap of provincial grain gap per capita in 2014

Note. China's provincial map has 32 units including the South Sea Islands, excluding Taiwan, Hongkong and Macao.

\section{The Prediction of China's Grain Gap between Supply and Demand in the Future}

The growth of food demand in China comes from two aspects: one cause is the slow growth of the population. The total population of China will maintain a low growth rate of about 5/1000 until 2030 and reached maximum peak of 1.6 billion. Then China population will begin to decline afterwards. The second cause is the growth demand of grain by poverty, which brings about a 1/1000 increase in total grain demand. By the end of 2015, there are still 80 million people in China living under food insecurity. The China's government puts forward the policy of "Accurate Poverty Alleviation" in 2016. Subsequently, local governments ensure to achieve the goal of poverty alleviation in the next five years to their superior government.

Therefore, China's total grain output in the next 15 years will still need to maintain a growth rate of up to 6/1000 in order to ensure the grain target of over $90 \%$ self-sufficiency, which has been proposed by China central government. Can China achieve this goal? Or is it that China can feed itself in the next 15 years? The stable growth of grain output per units is the answer to this goal in China. 
In the four factors to grain output growth in China, there will be a little change of ACL, MCI and GPP in the future. Next, we use the Exponential Smoothing Method of Hoter-Winter No-Seasonal method to predict the variation trend of OFPPU.

Using Stata 14.0 software, we establish the Hoter-Winter No-Seasonal model of OFPPU from 1995 to 2014. The prediction formula used in the forecast period is as follows:

$$
\text { OFPPUF }_{\mathrm{T}+\mathrm{K}}=\mathrm{a}_{\mathrm{T}}+\mathrm{b}_{\mathrm{T}} \times \mathrm{k}=5389.05+40.19 \times \mathrm{K} \quad(\mathrm{Kg} / \mathrm{ha})(\mathrm{k}=1,2,3, \ldots)
$$

In the formula, $\mathrm{T}=20$ (end of sample). The predicted results are found in Table 6 .

Table 6. Results of the predicted OFPPU (Unit: $\mathrm{Kg} / \mathrm{ha}$ )

\begin{tabular}{lllllllll}
\hline year & 2015 & 2016 & 2017 & 2018 & 2019 & 2020 & 2021 & 2022 \\
\hline OFPPUF & 5429.24 & 5469.43 & 5509.63 & 5549.82 & 5590.01 & 5630.21 & 5670.40 & 5710.59 \\
\hline year & 2023 & 2024 & 2025 & 2026 & 2027 & 2028 & 2029 & 2030 \\
\hline OFPPUF & 5750.78 & 5790.98 & 5831.17 & 5871.36 & 5911.56 & 5951.75 & 5991.94 & 6032.14 \\
\hline
\end{tabular}

The results of predicted OFPPU by Exponential Smoothing Method of Hoter-Winter No -Seasonal in Table 6 shows that China's grain production per unit area will increase stablely from $5429.24 \mathrm{Kg} / \mathrm{ha}$ in 2015 to 5750.78 $\mathrm{Kg} / \mathrm{ha}$ in 2030 , while the growth rate of grain output per unit area will be reduced from $0.7403 \%$ in 2016 to $0.6847 \%$ in 2030 . Fortunately, in the next 15 years, China's will keep average $0.7045 \%$ growth rate of grain output per unit area, which is higher than $0.6 \%$, the demand rate of grain growth for China's population growth and living improvement.

\section{Conclusion}

This article focuses on China's grain security, one of top world concern. It describes the general situation of China's grain output and import after 1978, and compares the China's grain supply with its neighboring countries. LMDI decomposition from 2003 to 2014 shows that the increase of OFPPU paied biger contribution than ACL, MCI or GPP to China's total grain output increase during 2003-2014, which led to total grain output increase of 1115.21 million tons or $24.24 \%$. The conclusion of China's grain output provincial spatial analysis is that the six provinces including Heilongjiang, Henan, Inner Mongolia, Jilin, Anhui and Shandong, contributed $62.2 \%$ share to China's total grain output increase from 2003 to 2014. The results of predicted OFPPU by Exponential Smoothing Method of Hoter-Winter No-Seasonal is that grain growth in China can meet grain security requirement for China's population growth and living improvement.

The biggest challenge of China's grain security outlook is deterioration of the ecological environment. Greenhouse gases emission and discharge of 'The Three Wastes' (industrial wastewater, waste gases and residues) increased rapidly along with the acceleration of urbanization and industrialization in China. The extreme natural disasters occured frequently in past ten years. The water shortage became quite frequent in Northern China. So China should increase investment for land consolidation, renovate facilities for farmland and water conservancy projects to ensure the basic cultivation conditions of arable land.

\section{References}

Ang, B. W. (2005). The LMDI approach to decomposition analysis: A practical guide. Energy Policy, 33, 867-871. http://dx.doi.org/10.1016/j.enpol.2003.10.010

Ang, B. W., \& Liu, F. L. (2001). A new energy decomposition method perfect in decomposition and consistent in aggregation. Energy, 26, 537-495. http://dx.doi.org/10.1016/S0360-5442(01)00022-6

Ang, B. W., Zhang, F. Q., \& Choi, K. H. (1998). Factorizing changes in energy and environmental indictors through decomposition. Energy, 23, 489-495. http://dx.doi.org/10.1016/S0360-5442(98)00016-4

Elisabeth, S., Evan, D. G. F., Mette, T., Piers, M. F., \& Andrew, J. D. (2008). Typologies of crop-drought vulnerability: an empirical analysis of the socio-economic factors that influence the sensitivity and resilience to drought of three major food crops in China (1961-2001). Environmental Science and Policy, 4, 438-452.

Hong, Y., \& Xiubin, L. (2000). Cultivated land and food supply in China. Land Use Policy, 2, 73-88.

Hong, Y., Yuan, Z., \& Junguo, L. (2009). Land and water requirements of biofuel and implications for food supply and the environment in China. Energy Policy, 5, 1876-1885. 
Jie, C. (2006). Rapid urbanization in China: A real challenge to soil protection and food security. Catena, 1, 1-15.

Lester, R. B. (1995). Who Will Feed China? Wake-Up Call for a Small Planet. W. W. Norton \& Company, New York.

Peter, H. V., Youqi, C., \& Tom, A. V. (2000). Spatial explorations of land use change and grain production in China. Agriculture, Ecosystems and Environment, 1, 333-354.

Zhigang, X., Jintao, X., Xiangzheng, D., \& Jikun, H. (2005). Grain for Green versus Grain: Conflict between Food Security and Conservation Set-Aside in China. World Development, 1, 130-148.

\section{Notes}

Note 1. September 1980, the CCCC opened a letter named "How to control the growth of China's population problem" to all Party members and Communist Youth League, the main content of the open letter is "promoting a couple only birth single child". Family planning has become a basic national policy for China since then. In the city, couples only allow single child birth, except couple can have two children birth if they are both single children. In the countryside, couple allow second child if their first child is a girl except for farmers living inYunnan, Qinghai, Ningxia, Xinjiang and Hainan province; Farmers in Tibetan have no restriction numbers of children.

\section{Copyrights}

Copyright for this article is retained by the author(s), with first publication rights granted to the journal.

This is an open-access article distributed under the terms and conditions of the Creative Commons Attribution license (http://creativecommons.org/licenses/by/4.0/). 